\title{
Difficulties in Teaching English for Specific Purposes: Empirical Study at Vietnam Universities
}

\author{
Nguyễn Thị Tố Hoa ${ }^{1} \&$ Phạm Thị Tuyết Mai ${ }^{1}$ \\ ${ }^{1}$ Vietnam National University, Hanoi, Vietnam \\ Correspondence: Phạm Thị Tuyết Mai, International School, Vietnam National University, Building C, \\ HACINCO Student Village, No. 99 Nguy Nhu Kon Tum, Thanh Xuan district, Hanoi, Vietnam. E-mail: \\ maiptt@isvnu.vn
}

Received: March 29, 2016

Accepted: April 21, $2016 \quad$ Online Published: May 10, 2016

doi:10.5539/hes.v6n2p154

URL: http://dx.doi.org/10.5539/hes.v6n2p154

\begin{abstract}
In recent years, teaching English, especially English for specific purposes at Vietnam universities has received a lot of attention from students, teachers, and relevant authorities because of not high teaching effectiveness. This results in the fact that students after graduation do not meet English requirements of employers, so unemployment becomes more serious. This is an alarming situation because English is becoming the almost indispensable communication language of young people nowadays. This empirical study consists of a survey of teachers and students at universities in Hanoi by listing the factors related to teaching English for specific purposes. Then, we give some recommendations for improving effectiveness of teaching English for specific purposes so that students can meet the English requirements for their work and lives.
\end{abstract}

Keywords: teaching English, learning English, foreign language for specific purposes, Vietnam

\section{Introduction}

In the trend of modernization and integration, English is the third widely used language in the world with 335 million users as native language and 110 countries using it as an official language. Also, English attracts the greatest number of learners around the world (1.5 billion learners-according to Ethnologue, 2015). It plays an increasingly important role in the development of science, technology, politics, economics, culture and international relations. Therefore, the demand for teaching and learning English, especially English for specific purposes is rising, not only for communication purpose. Courses of English for specific purposes are receiving a lot of attention, especially in universities.

However, in fact, teaching and learning English for specific purposes in Vietnam are still ineffective and do not meet the society needs. According to Vietnam Department of Higher Education, there are only about $49.3 \%$ of students after graduation meeting employers' English requirements; nearly 19\% of those not meeting employers' English requirements; and nearly $32 \%$ needing to be trained further. Even for majors closely related to English such as Television Journalism (the Academy of Journalism and Communication), there are more than $1 / 3$ of the students retaking their exams of English for specific purposes. Besides, teachers' qualification and teaching methods; lack of time; classes with too many students; not regularly updated textbooks, etc., pose many challenges for teaching and learning this subject.

For those reasons above, our research focuses on "Difficulties in teaching English for specific purposes: empirical study at Vietnam universities". On the basis of analyzing actual situation of teaching English for specific purposes in Vietnam universities, we will propose relevant recommendations for students, teachers, Vietnam universities, Vietnam Ministry of Education and Training and relevant authorities.

\section{Theoretical Framework}

Hutchinson and Waters (1987) defined English for Specific Purposes (ESP) was a language learning approach based on learners' needs. Đỗ and Cái (2010) suggested that ESP was English courses based on survey results and needs analysis in order to determine the specific activities that students have to do as well as the final goal they have to achieve. Thus, ESP is an English course of which the textbooks and materials are adjusted to learners' desires and purposes. 
Dudley-Evans and St John (1998) suggested the ESP characteristics as following: (1) ESP meets specific purposes of the learners; (2) ESP makes use of underlying methodology and activities of the discipline it serves; (3) ESP is centered on the language appropriate to these activities in terms of grammar, lexis, register, study skills, discourse and genre. Besides, ESP also has some variable characteristics such as: (1) ESP may be related to or designed for specific disciplines; (2) ESP may use, in specific teaching situations, a different methodology from that of general English; (3) ESP is likely to be designed for adult learners, either at a tertiary level institution or in a professional work situation. It could, however, be for learners at secondary school level. However, in some cases, ESP is also designed for high school students; (4) ESP is generally designed for intermediate or advanced students, and (5) Most ESP courses assume some basic knowledge of the language system, but it can be used with beginners.

There are several researches in the world on the difficulties in teaching ESP. These are divided into 03 main groups: (1) difficulties related to students; (2) difficulties related to teachers; (3) and difficulties related to environment and others.

\subsection{Difficulties Related to Students}

Demographic characteristics and demands of learning English for specific purposes of students: according to Suzini et al. (2011), the students' demand for ESP is not met adequately, as follows: (1) students are not ready for ESP courses; (2) ESP classes are often too large; (3) sometimes ESP classes are delayed or canceled for no obvious reason; (4) in some universities, the learners' motivation decreases because ESP courses are usually taken place in the summer; (5) students find that ESP is too different from general English; (6) ESP teaching methods are still passive; (7) ESP teachers' qualification is inadequate. Besides, most students are used to the traditional teaching and learning methods. This results in the fact that students are timid and passive when they take ESP courses; and do not find ESP important for their future job. This situation has a significant impact on learning motivation of individual students in particular and learning environment of class in general.

English proficiency: difference in students' proficiency in the same university and among different universities has a negative impact on teaching ESP. For example, students in foreign language universities or foreign language departments of universities have higher proficiency in comparison with that of technical departments (electronics, construction), social departments (philosophy, sociology) or other universities. Besides, residential area also has a significant impact on students' English proficiency. Usually, students from small towns have lower foreign language proficiency than those from big cities because teaching English at secondary school level in many Vietnam areas remains weak and inadequate. This creates the difficulty in using common ESP textbooks, especially for the students of departments not related much to English or at remote areas.

Differences between Vietnamese and English, especially English for specific purposes: difference of language, especially language for specific purposes between English and native language creates certain difficulties for learners. According to Maruyama (1996), Japanese has no relationship with English; and Japanese writing system is completely different from that of English. This makes Japanese students face a lot of difficulties in learning English, especially for the ESP terms. Also, Vietnamese has a lot of differences from English because many Vietnamese words derive from Chinese and the difference in pronunciation, grammar, etc. Therefore, it takes much time for Vietnamese learners to use English proficiently. Many learners give up when they can not remember and use ESP for their work.

Lack of vocabulary: according to Maruyama (1996), among students majoring in electrical engineering in Japan, he gave a list of 60 technical words to 112 students to identify the words and their meanings. However, there were 20 words none of the students knew, some words were known by a few students and only 1 word whose meaning all of 112 students understood. Since then, Maruyama (1996) pointed out the reasons for students' lack of vocabulary: (1) The students believed that they did not need to know words because they were not common, even rarely used in their daily lives; (2) Therefore, they had no motivation to learn the words, and (3) Most English teachers could not teach them these words because the teachers themselves were not well acquainted with these scientific terms. Maruyama's assessment has many similarities to the actual situation in Vietnam. Many students think that ESP terms are rarely used, especially in their daily lives, so they have no motivation to learn and remember them.

Dependence on dictionary and lack of skills in using dictionary: lack of vocabulary, especially ESP terms, makes many students depend on dictionary and get stuck whenever they encounter a new word (Maruyama, 1996). Specifically, when they see an entirely new word, they can not guess its meaning and nor can they ignore it to understand the text. That's because students have no knowledge of English etymology, so they can not 
understand meaning of a sentence when they do not know meaning of a word or a few words in it. As a result, this dependence limits the flexibility and imagination of learners.

Lack of skills in using dictionary is also a worrying problem. When using dictionary, many students only pay attention to the first meaning of a word and do not concern with its other meanings and usages. Besides, teachers do not often teach dictionary using skills to students.

Reading, listening, speaking and writing skills: concerning reading skill, Rezaei, Rahimi and Talepasan (2012) showed that most learners had difficulties in identifying and understanding syntaxes of sentences. This makes reading English more difficult and sometimes learners may understand incorrectly sentence meaning. The reason is that there are too few scientific and technology English articles in universities, so students are unfamiliar with ESP documents.

Concerning writing skill, Lâm (2011) believed that most students were facing problems related to vocabulary, organizing ideas, grammar and spelling. They are often impatient to outline, organize ideas logically and connect them together in their writings. This makes ESP texts of students very sketchy, shaky and sometimes they even identically copy other texts for their writings.

Concerning listening and speaking skills, students practiced these two ones very little in class because they spend most of their time learning grammar, vocabulary and reading text documents. Teachers do not pay attention to listening and speaking activities; and often give students two-language lectures (native language and English). Therefore, students only remember individual words and can not express their opinions in English for specific purposes.

\subsection{Difficulties Related to Teachers}

Quality of lectures and textbooks: in ESP courses now, most materials are designed to develop skills in listening, speaking, reading, writing and translation, but some teachers believe that a good vocabulary is enough for students. Therefore, a number of textbooks developed by teachers do not bring students much interest because of focus on only reading skills and vocabulary exercises. According to Lâm (2011), students often forget the learned words after each exam.

Qualification and Teaching Methods of teachers: the difficulties related to teachers include: teachers' qualification difference, teaching method difference, especially lack of specialized knowledge because they are not allowed to take part in refresher courses on methods and knowledge of teaching ESP. According to Ho (2011), teachers also face problems related to course design, tasks, assignments and teaching methods. In classes, students have to participate in group activities, presentations, taking minutes, writing essays about the learned knowledge/topics ... However, due to lack of time, lessons are sometimes not highly effective. Besides, learning efficiency assessment is not accurate because the majority of exams are designed by teachers.

Lack of Theoretical framework to support teaching English for specific purposes: Chen (2011) suggested that theoretical framework to support teaching English for specific purposes was the challenge of teaching ESP. The biggest problem is that there is no theoretical framework to support teaching ESP. There are many mixed opinions on whether this subject should be considered as a compulsory subject in the curriculum or should be considered as a skill or practical knowledge to help students more confident with their knowledge after graduation. Besides, classroom teacher is the one with specialized knowledge or the one with no specialized knowledge is also an unsettled issue.

\subsection{Difficulties Related to Environment and Others}

Lack of teaching materials: in many ESP training institutions now, technical facility for teaching ESP is mainly CD player; meanwhile, PowerPoint and electronic lessons are rarely used. Besides, ESP document is often developed by teachers with no specialized knowledge, so the quality of those materials is not high. Maruyama (1996) suggested that the ESP materials which are at too high level compared to students' proficiency made students feel bored to learn. In addition, students can not expand their understanding because of limited knowledge of the textbook. Many students admit that they learn ESP because they have to learn but they want to; and no longer remember learned knowledge after exams.

Classes with too large student number: according to Maruyama (1996), most students must take at least two years to learn English in universities, so student number of a class is up to 70-90. This has a significant impact on ESP teaching efficiency, especially when there is the difference in students' proficiency. Most students find it too difficult or too easy compared to their knowledge. Therefore, students do not have the motivation to study this subject. 
Heavily focused examination: heavily focused examination is also a big challenge for teaching ESP in universities, especially in Northeast Asian countries (Japan, Korea, China, Vietnam, ...). For example, in Japan, it is believed that the admission in a prestigious school from kindergarten to university is a prerequisite to ensure a good future for their children (Maruyama, 1996). This results in highly competitive exams. However, the effectiveness of these exams is not high because after these exams, students usually quickly forget learned knowledge.

\section{Methodology}

This research is based on a literature review on foreign language education in Vietnam and several countries in Southeast Asia in recent years. In addition, we conduct a survey for students and teachers in Vietnam universities (mostly in Hanoi). Thus, the data are accurate and up-to-date. In fact, we establish a questionnaire of 12 difficulties involved in the literature review and information about students and teachers' sexes and universities. Then, the questionnaires are handed to the students and teachers at universities mainly in Hanoi for collecting their comments on teaching ESP. The participants give their comments on a scale of one to five for each question (1-Very difficult; 2-Difficult; 3-Normal; 4-Favourable; 5-Very favourable). After the survey, the data are classified into different categories (theory, reference, survey ...) by removing inappropriate or unnecessary information. Then, the information is selected based on the outline laid out; and is analyzed to highlight the situation.

There are more than 400 students and teachers at 11 universities participating in the survey. We get 362 valid replies. Most of the students are in third year and learned ESP in universities. The majority of students and teachers are at Vietnam University of Commerce; University of Transport and Communications; Hanoi National University of Education; and Hanoi University of Science and Technology (12\%-14\%).

Table 1. Research sample

\begin{tabular}{lcc}
\hline \multicolumn{1}{c}{ University } & Frequency & $\%$ \\
\hline Vietnam University of Commerce & 51 & $14,09 \%$ \\
University of Transport and Communications & 45 & $12,43 \%$ \\
Hanoi National University of Education & 45 & $12,43 \%$ \\
Hanoi University of Science and Technology & 45 & $12,43 \%$ \\
Foreign Trade University & 36 & $9,94 \%$ \\
Hanoi University & 36 & $9,94 \%$ \\
National Economics University & 32 & $8,84 \%$ \\
Academy of Finance & 30 & $8,29 \%$ \\
University of Languages and International Studies & 24 & $6,63 \%$ \\
Banking Academy & 16 & $4,42 \%$ \\
University of Social Sciences and Humanities & 2 & $0,55 \%$ \\
\multicolumn{1}{c}{ Total } & 362 & $100,00 \%$ \\
\hline
\end{tabular}

\section{Findings \& Discussion}

\subsection{Overview of Teaching and Learning English at Vietnam Universities}

The worrying problem for teaching English at Vietnam universities concerns a large proportion of students lacking general English and ESP. A survey among 18 Vietnam universities in 2015 found that the average score of first-year students reached 220-245/990 points in TOEIC test. This means students need about 360 hours of learning (equivalent to 480 classes) in order to reach 450-500/990 points TOEIC-the minimum score required by employers. However, in fact, there are only about 225 English classes for students to practice 4 important skills (listening, speaking, reading and writing).

Currently, university English curriculum is built in the framework of Vietnam Ministry of Education and Training. This includes 90-210 classes; and mainly focuses on grammar, reading documents or basic-level communication, not English skill development. In addition, the number of general English classes is always 
greater than that of ESP. As a result, Vietnamese students' English grammar is often good; meanwhile, their communication ability is still weak. So, unemployment is still high. Approximately $50.7 \%$ of graduates do not meet the English requirement of employers (According to Vietnam Higher Education Department, 2015).

In addition, lack of teaching materials and incomplete textbook content are a big issue for teaching ESP. The fact is that ESP textbooks only focus on grammar and vocabulary; and are sometimes compiled from a variety of sources or use foreign documents. This makes textbook contents inconsistent and inappropriate to Vietnam actual situation.

Teaching ESP is still ineffective because teachers are not trained specialized knowledge. Many general English teachers admit that they can not teach ESP because they themselves do not fully understand the specialized terminology. Even general English teachers at upper secondary schools do not meet the requirements for teaching qualification. According to statistics, only $14 \%$ of lower secondary school teachers and $4 \%$ of upper secondary school teachers in Hai Duong province meet teaching requirements; meanwhile, in Ho Chi Minh city, there are only $5 \%$ for both lower and upper secondary school.

Vietnam's National Foreign Languages 2020 Project on teaching ESP has been implemented since 2010. According to this, up to $2015-2016,60 \%$ of university, college and high school students must be taught ESP, but in fact there are only $35 \%-40 \%$. Therefore, it is very difficult for Vietnamese students to improve global English proficiency ranking (No. $8 / 20$ of the ability to read-write and 18/20 of the ability to listen-speak, the British Council in 2011). The proportion of students after graduation who are not confident with their English skills is very high.

\subsection{Actual Situation of Teaching English for Specific Purposes}

The results of our empirical study indicate that:

Table 2. Results of our empirical study

\begin{tabular}{|c|c|c|c|c|c|}
\hline Difficulties & Very difficult & Difficult & No problem & Easy & Very easy \\
\hline Differences between Vietnamese and English & $35.91 \%$ & $34.53 \%$ & $17.40 \%$ & $6.63 \%$ & $5.52 \%$ \\
\hline Lack of vocabulary & $35.08 \%$ & $24.86 \%$ & $27.35 \%$ & $11.05 \%$ & $1.66 \%$ \\
\hline Dependence on dictionary & $29.01 \%$ & $24.86 \%$ & $36.19 \%$ & $3.31 \%$ & $6.63 \%$ \\
\hline Listening skills & $7.18 \%$ & $25.97 \%$ & $54.97 \%$ & $11.33 \%$ & $0.55 \%$ \\
\hline Speaking skills & $5.25 \%$ & $14.64 \%$ & $59.94 \%$ & $18.78 \%$ & $1.38 \%$ \\
\hline Reading skills & $6.08 \%$ & $8.01 \%$ & $54.70 \%$ & $29.56 \%$ & $1.66 \%$ \\
\hline Writing skills & $6.63 \%$ & $9.39 \%$ & $62.71 \%$ & $19.89 \%$ & $1.38 \%$ \\
\hline Quality of lectures and textbooks & $37.02 \%$ & $17.68 \%$ & $22.38 \%$ & $14.92 \%$ & $8.01 \%$ \\
\hline Qualification and Teaching Methods of teachers & $10.22 \%$ & $46.69 \%$ & $22.65 \%$ & $16.85 \%$ & $3.59 \%$ \\
\hline Lack of Theoretical framework & $3.04 \%$ & $46.41 \%$ & $27.07 \%$ & $21.27 \%$ & $2.21 \%$ \\
\hline Lack of teaching materials & $3.04 \%$ & $25.14 \%$ & $55.25 \%$ & $11.33 \%$ & $5.25 \%$ \\
\hline Classes with too large student number & $47.24 \%$ & $10.50 \%$ & $22.38 \%$ & $16.85 \%$ & $3.04 \%$ \\
\hline Heavily focused examination & $20.44 \%$ & $33.43 \%$ & $37.29 \%$ & $6.91 \%$ & $1.93 \%$ \\
\hline
\end{tabular}

- Difficulties related to students

The majority of respondents do not believe that demographic characteristics and demands of learning ESP of students have a negative impact on teaching ESP. In particular, $44.75 \%$ think that these factors do not have a significant impact on teaching ESP; $21 \%$ think that the ones have a positive impact on teaching ESP. However, most of the respondents $(66.02 \%)$ believe that students' language proficiency now is a big challenge for teaching and learning ESP. The difference in students' language proficiency among universities and among areas has a negative impact on teaching ESP.

According to $70.44 \%$ of respondents, the reason why they have difficulties in teaching and learning ESP is due to the big difference between Vietnamese and English involving parts of speech, pronunciation, word usage and grammar. Many long and difficult ESP words as well as complex structures in scientific articles creates 
difficulties in teaching ESP. This results in the lack of English vocabulary among Vietnam students'. The survey results show that $59.94 \%$ have difficulty in vocabulary. Therefore, they depend heavily on the dictionary. There are $53.87 \%$ of respondents who think that dependence on the dictionary causes difficulties in teaching ESP. Meanwhile, $36.19 \%$ of the ones having skills in using dictionary evaluate this factor not to have a significant impact on teaching ESP.

According to the survey results, the majority of students and teachers find that 4 skills of listening, speaking, reading and writing are not too difficult for them (Listening skill: 54.97\%; Speaking skill: 59.94\%; Reading skill: $54.70 \%$; Writing skill: $62.71 \%$ ). The proportion of students having difficulty with these skills is relatively small. Listening skill is the most difficult one (33.15\%), the next are speaking skill (19.89\%), writing skill (16.02\%); and reading skill (14.09\%). Thus, reading skill is considered as the easiest one which helps students understand ESP books and articles.

Precisely, Vietnam students are facing many difficulties in learning ESP. Although their demands of learning it is increasingly high, teaching ESP at Vietnam universities heavily focuses on grammar and vocabulary. Meanwhile, English communication skills are neglected, this negatively influences students' ability to find job after graduation.

\section{- Difficulties related to teachers}

$54.70 \%$ of respondents think that the quality of lectures and textbooks brings about difficulty in learning and teaching ESP. In fact, the lectures and textbooks at Vietnam universities still have many shortcomings, such as heavy focus on theory, not scientific and practical content ... Besides, the majority (56.91\%) of respondents believe that teachers' qualification and teaching methods are also big challenge for teaching ESP, especially theoretical framework to support teaching it. Up to $49.45 \%$ of the respondents, the majority of whom are teachers, suggest these factors makes teaching ESP more difficult. The fact is that many teachers have English certificates but can not teach ESP due to poor listening skills. Some teachers are good at 4 English skills but lack specialized knowledge, so their lectures are not lively and attractive to students. Meanwhile, the number of native English-speaking teachers trained in their major is still small.

- Difficulties related to environment and others

These factors also have a significant impact on teaching ESP at Vietnam universities. 55.25\% consider that the ones do not cause difficulty in teaching ESP. Vietnam universities now focus more on the equipment investment, especially for teaching English, such as: classrooms equipped with projectors and the library with many computers connected to the internet. However, classes with too large student number and heavily focused examination have a negative impact on teaching ESP. Now, English classes usually have 40 students or more. Moreover, the difference in students' language proficiency makes teaching ESP more difficult. Meanwhile, most Vietnamese students are passive learners and have no real interaction with the teachers.

Heavily focused examination is still common in Vietnam. Most people prefer their children to study or work at prestigious universities with good degrees for facilitating the access to large firms with high salaries. Therefore, many students admit their learning purpose of high scores and they quickly forget most of the learned knowledge. Thus, heavily focused examination makes students learn passively and decrease their proficiency.

In sum, teaching English for specific purposes is facing many difficulties arising from subjective and objective factors. These difficulties have a direct impact on teaching ESP and students' ability to find jobs after graduation. For improving ESP teaching effectiveness, there should be collaboration between students, teachers and universities as well as the relevant authorities.

\section{Implications of the Results}

\subsection{Recommendations for Students}

Firstly, they should clearly determine learning objectives by enhancing the learning responsibility (regular class attendance, paying attention to the lectures ...). Students also need to create the ESP learning motivation by determining real scores, number of English words and practicing them in the work.

Secondly, they should be more active in learning by interacting more with teachers and participating in activities and tasks such as discussions, presentations and group activities. In addition, students can also gain more knowledge and skills by taking part in clubs and teams at universities.

Thirdly, they need to enhance the knowledge by finding more materials, especially specialized documents. Initially, students can find bilingual materials, then English specialized documents for improving reading comprehension skills. 
Fourthly, they should spend more time practicing the English skills of listening, speaking, reading and writing; and focusing on the weak skills. Besides, students need to practice two important skills for learning ESP, including translation skills and skills in using dictionary by establishing small groups or attending skills training courses; and sharing knowledge with friends.

Fifthly, they should find part-time jobs requiring to use English, especially English for specific purposes for the opportunity to practice regularly the learned knowledge. This also enhances learning motivation and makes students more confident after graduation.

\subsection{Recommendations for Teachers}

Firstly, they must improve their language knowledge, especially English for specific purposes; increase lecture attraction by finding more ESP materials and learning from others' experience. This allows them to expand their understanding.

Secondly, their professional experience should be improved by actively participating in domestic and overseas professional training courses; and sharing experience with other teachers. This helps expand the relationship and enhance professional experience.

Thirdly, they should apply information technology to lectures for increasing lectures' attraction as well as saving time and effort. This increases teaching efficiency, especially when equipment investment at universities receives greater attention.

Fourthly, they need to establish closer relationships with students in the classroom, especially with bad students to understand and share the difficulties that they encounter. Teachers should divide the class into groups of students with different levels. In addition, teachers should also encourage students to participate in listening and speaking skill training classes.

Fifthly, they should regularly update teaching methods by reducing grammar and focusing on the skills of students. Teachers can give more practical examples and organize trips for specialized knowledge which help students better understand their major.

\subsection{Recommendations for Vietnam Universities, Vietnam Ministry of Education and Training, Vietnam State and Authorities}

Universities should allocate time among the subjects more reasonably by increasing the practical classes and focusing more on ESP. The reason is that students can improve their English by participating in extra classes; meanwhile, they can learn ESP only at universities with appropriate curriculum and experienced teachers.

Universities should adjust the student number of English classes (about 20 students in a class). This helps students have more opportunities to practice ESP. Besides, decreasing the gap of students' proficiency difference raises teaching and learning motivation.

Universities need to invest more in teaching materials, especially textbooks by actively coordinating with domestic and overseas universities to develop ESP textbooks in line with Vietnam students' qualification and Vietnam actual situation.

We should increase the cooperation among universities in Vietnam and in the world in order to increase the opportunities for learning and sharing experiences and knowledge among teachers. Vietnam Ministry of Education and Training can organize seminars for enhancing teachers' qualification.

Finally, Vietnam State, Vietnam Ministry of Education and Training and relevant authorities should reduce examination pressure for students by improving their real proficiency. Also, accurate assessment of students' learning effectiveness is very important.

\section{Concluding Remarks}

This study involves the factor groups of students; teachers; and environmental factors and others having an impact on teaching and learning English for specific purposes in Vietnam. Based on theoretical framework of foreign scholars, we explain the impact of each factor on teaching ESP in the world as well as in Vietnam. Moreover, we conducted a survey of 362 teachers and students in 11 Hanoi ESP training universities. The survey results show that teaching and learning English for specific purposes in Vietnam still face many difficulties. Therefore, supports of students, teachers and relevant authorities are very important. Our recommendations were proposed based on Vietnam actual situation and could be effectively applied to each involved subject.

Due to limited study time, the scope and contents of the survey are limited. This study can be developed in many different directions, such as teaching English for specific purposes at a certain university or English for a specific 
purpose at many different universities in Vietnam. Surely, then recommendations will be more specific and easier to understand for improving teaching and learning English for specific purposes in Vietnam.

\section{References}

Chen, Y. (2011). The institutional turn and the crisis of ESP pedagogy in Taiwan. Taiwan International ESP Journal, 3(1), 17-30.

Đỗ, T. X. D., \& Cái, N. D. A. (2010). Teaching and learning English in new context: Challenges and solutions [Dạy và học tiếng anh chuyên ngành trong tình hình mới: Thách thức và giải pháp; trad]. Tạp chí khoa họ Đại học Huế, 60.

Dudley-Evans, T., \& St John. (1998). Research perspectives on English for academic purposes: A Multi-Disciplinary Approach. Cambridge: Cambridge Universiti Press.

Ho, B. (2011). Solving the problems of designing and teaching a packed English for specific purposes course. New Horizon in Education, 59(1), 119-136.

Hutchinson, T., \& Waters, A. (1987). English for Specific Purposes: A learning-centred approach. Cambridge, Cambridge University Press. http://dx.doi.org/10.1017/cbo9780511733031

Lâm, Q. Đ. (2011). English for specific purposes: Problems of teaching contents [Tiếng Anh chuyên ngành: Một số vấn đề vệ nội dung giảng dạy; trad]. Báo Ngôn ngũ và Đời sống số-Language \& Life, 11(193).

Maruyama, H. (1996). Difficulties in Teaching Technical English in Japan. Revista de Lenguas para Fines Especificos, 3.

Rezai, A., Rahimi, M. A., \& Talepasan, S. (2012). Exploring EFL learners reading comprehension problems in reading ESP texts. Sino-US English Teaching, 9(3), 982-987.

Suzani, S. M., Yarmohammadi, L., \& Yamini, M. (2011). A critical review of the current situation of teaching ESP in the Iranian higher education institutions. The Iranian EFL Journal, 7(6), 179-204.

\section{Copyrights}

Copyright for this article is retained by the author, with first publication rights granted to the journal.

This is an open-access article distributed under the terms and conditions of the Creative Commons Attribution license (http://creativecommons.org/licenses/by/3.0/). 